On October 30, 1966 a Red Phalarope was seen on Cochrane Lake by Bob Masters and ourselves. Cochrane Lake is about 20 miles west of Calgary. This bird also was in winter plumage, and we viewed it about 40 feet from the shore with a 30-power scope. The weather was cool and windy as dusk approached. Once again, however, because of the unstreaked back, stouter bill and yellowish legs we felt positive that our identification was correct.

\section{MORE BALD EAGLE SIGHTINGS IN THE LAKE ATHABASCA REGION}

by Brian Wood, 34 Qu'Appelle Apts., Regina

As an addition to Wayne Davis' account of Bald Eagle (Haliaretus leucocephalus) sightings (Blue Jay, $24: 160-167)$, I would like to report the location of three nests northwest of Lake Athabasca (74-N-14-W) in the summer of 1966 . The area referred to is in the northern part of the Canadian Shield in a region of granite rock outcrop, muskeg, and jack pine.

On June 2, two mature eagles were sighted near Nettle Lake. During the following week these eagles were observed frequently but no nest site was located.

Two eaglets in the down condition were observed at Dragon Lake on June 10. Their nest was located in a live jack pine approximately 20 yards from the lake.

On my return to Nettle Lake, June 13, a pair of mature eagles was located with their nest containing young. This nest was located in a prominent jack pine about 40 yards from the lake. The young were very vociferous but unable to leave the nest. Although I could not observe the nest, nest building material up to one inch in diameter was found at the base of the tree. Droppings were numerous and three unidentified fish skeletons were found four yards from the tree. I don't believe these were the same eagles as the ones seen on June 2. In eight sightings the birds seen previously were never observed near the area in which the eagles with the young were located.

On August 14 another Bald Eagle nest containing young was located on Northwest Bay of Tazin Lake but it was impossible to determine the number of young.

\section{P.N.R.S. NEST RECORDS FOR} 1967

Careful records of breeding birds, both common and uncommon, add to our information about resident species. Every birder familiar with the local species in this area is urged to complete nest records cards and submit them to

\section{PRAIRIE NEST RECORDS SCHEME}

SNHS, Box 1121, Regina, Sask.

Any person who can contribute should write for cards (give estimated number needed) to the above address.

\section{CO-OPERATIVE SPRING MIGRATION STUDY}

Records are again requested for the continent-wide survey being made under the auspices of the U.S. Fish and Wildlife Service. As soon as it is available, we shall have a list of species for which reports are wanted; please write for the list and then submit your records by June 15, 1967, to

Mrs. Mary Houston

863 University Drive, Saskatoon

\section{LOOK FOR OWL NESTS}

If you know of any nesting Great Horned Owls, or other owls, please write or telephone collect as soon as you find the nest, to

Dr. Stuart Houston or

Mrs. Stuart Houston

863 University Drive, Saskatoon.

Telephone 244-0742 